\title{
18. Children and parents after separation
}

\author{
Ulrike Zartler
}

\section{INTRODUCTION TO POST-DIVORCE PARENT-CHILD RELATIONS}

In recent years, the divorce rates in some European countries have levelled off, or have even declined. However, pointing to this trend may give a misleading impression of family stability, because cohabiting unions - which are on the rise, and are often less stable than marital unions - are not included in these statistics (Cherlin 2017; see also Mortelmans in this volume). Life table estimations based on the Generations and Gender Survey for 19 countries have revealed considerable variation across countries in the proportions of children who experience a parental separation or divorce ${ }^{1}$ before reaching age 15 (Andersson et al. 2017): these shares are highest in the United States, at 44 per cent, and in the Russian Federation, at 42 per cent; are around one-third in France, Estonia, Lithuania, and the Czech Republic; are slightly higher than 20 per cent in Nordic and Central European countries; and are lowest in Southern European countries, at around 10 per cent. In all European countries, the chances of experiencing a parental separation are higher for children born to parents who are cohabiting rather than to parents who are married. Divorce and separation change children's and parents' lives in various ways.

A parental break-up is associated with numerous changes, including the need to reorganise relations between the parents and their children. In some countries, shared legal custody is the default custody arrangement after separation and divorce. In other countries, child custody is a matter of negotiation between the parents. Thus, the parents have to decide whether their children will live mainly with one parent (the so-called residential parent), or whether they will practise shared parenting. This implies that the parents have to find ways to organise multi-local parenting. If the child primarily lives with one parent, contact with the non-resident parent must be organised. In addition, the dissolution of a union entails significant changes in the financial situations of the parents, and often leads to a decline in the standard of living of the mother in particular (see the chapter by Mortelmans). If the parents re-partner, family complexity will increase further. Thus, after their partnership has been terminated, parents face pressure to find ways to maintain emotional bonds with their offspring, and to sustain their parental relationship with their children. Meanwhile, the children are having to adapt to a large number of divorce-related changes to their lives, and to the introduction of new rules and routines.

This contribution sheds light on the relationships between children and their parents after a parental break-up. The main questions I address are as follows: How do children and parents relate to one another after a divorce, and what challenges do they face in adjusting to their new situations? In this chapter, I consider the effects of the dissolution of marital and cohabiting unions on parent-child relations. While my main focus is on research from Europe, I also take into account results from the United States, where a large number of studies on this topic have been carried out. The chapter is structured as follows: first, I describe the key theoretical 
approaches that seek to explain post-divorce parent-child relations. In the subsequent section, I present the main results of empirical studies on the impact of divorce on children, parents, and parent-child relations. I then discuss some of the major challenges children and parents encounter after a divorce. These challenges include difficulties obtaining and providing adequate information, normative disadvantages, management of post-separation family lives, multiple transitions, and family complexity. Moreover, I outline in a separate section the issues surrounding custody and contact after parental divorce. I close this contribution with a short summary of my findings, and some recommendations for future lines of research.

\section{THEORETICAL APPROACHES}

From a theoretical point of view, divorce has long been regarded as a discrete, negative, normatively undesirable event that disrupts family life and leads to disorganisation. This view has shifted towards a conceptualisation of divorce as a gradual and complex process that begins long before the legal divorce and unfolds over time, reshaping and restructuring family relationships (Amato 2000). In this framing, divorce does not result in disorganisation, but in a reorganisation and a transition of the family system. Thus, just as the post-divorce family arrangements may contribute to more positive or negative outcomes, the pre-divorce family environment also affects how children and parents adjust to divorce.

The focus of family sociology has shifted from cross-sectional research of family structures - i.e., how parents and children are related in their family or household - to the analysis of family instability and family transitions. Accordingly, recent research on separation and divorce has been paying more attention than previous studies to the transitions from one family structure to another. In this vein, the family instability hypothesis focuses on family transitions that occur when a parent forms or dissolves a partnership. It conceptualises parental divorce and separation as the first step in a series of family developments that contribute to instability via the formation and break-up of new unions; and, from the perspective of the child, via the acquisition of stepparents, half-siblings, and/or stepsiblings (Amato 2010; Fomby and Cherlin 2007; Hadfield et al. 2018; Osborne and McLanahan 2007; Shafer et al. 2017). The instability hypothesis suggests that family transitions are stressful events that lead to adverse developmental outcomes for parents and children. Hence, a large number of studies have shown that divorce and separation are stressful transitions for parents and children alike. Parents who are in the process of divorcing often experience emotional tension, task and responsibility overload, financial drawbacks, and difficulties maintaining positive parent-child relationships. These burdens can make it hard for parents to provide their children with a consistent routine and a stable family environment. Apart from observing their parents' stress and dealing with a decline in their standard of living, the children of divorcing parents may experience feelings of insecurity, fear, anger, loyalty conflicts, guilt, or self-blame (Birnbaum and Saini 2012).

In line with this approach, the divorce-stress-adjustment perspective explores the effects of stress on families undergoing a break-up (Amato 2000): events that adults and children experience as stressful, or 'stressors', increase their risk of negative emotional, behavioural, and health outcomes. Potential stressors for divorcing parents include having to take on the sole responsibility for parenting, losing custody of their children, dealing with the loss of emotional support, and managing continuing conflict with the ex-spouse. Potential stressors for children of divorcing parents include having less parental support overall, having less 
contact with one parent, and dealing with continuing conflict between their parents; as well as having to move to another home or school, and resulting changes in their social networks. Furthermore, the economic strain and the decline in living standards associated with divorce causes hardships for both parents and children. However, there are also protective factors, or 'moderators', that can weaken the negative impact of stressors following a divorce. These moderators are socio-economic, individual, interpersonal, and structural resources that can reduce the negative effects of divorce and separation. Potential moderators include positive social and legal support when undergoing divorce or separation, and favourable demographic characteristics. Although divorce and separation can have long-term economic, mental health, and social consequences, most children and parents recover from and adapt to the break-up in the medium term (Amato 2010).

Family instability and complexity is theoretically connected with the concept of family boundary ambiguity, which refers to a state in which family members 'are uncertain in their perception about who is in or out of the family and who is performing what roles and tasks within the family system' (Boss and Greenberg 1984, p. 536). This concept acknowledges that family structure is not an 'objective' fact, as it may be perceived differently by different members of the household or family. For example, when people who live in the same household are asked who is part of the family, they often give different and sometimes contradictory responses, especially if they are involved in stepfamilies or post-divorce families (Castrén and Widmer 2015; Zartler 2011). Brown and Manning (2009) showed for the United States that the greater the family complexity, the more likely it was that the family structure reported by an adolescent deviated from that of his/her mother. In cases in which the mothers reported living in a married stepfamily, only 70 per cent of the children reported living in the same family structure. This pattern was most pronounced for cohabiting stepfamilies, among whom there was agreement in only one-third of cases. From a theoretical perspective, these findings suggest that divorce and separation may exacerbate boundary ambiguity, which could, in turn, make post-divorce reorganisation more difficult. The lack of clarity about family membership has been shown to be associated with family stress, reduced feelings of belonging or connectedness, lower couple relationship quality, diminished parental involvement, increased levels of parental conflict, dissatisfaction with parenting, and reduced child well-being (Brown and Manning 2009; Stewart 2005).

The instability hypothesis is often contrasted with the selection hypothesis, which states that the relationship between family transitions and child outcomes is spurious, as both are caused by the parental characteristics that are correlated with divorce and separation, like their educational levels, occupational status, or socio-economic status (Cherlin 1999; Fomby and Cherlin 2007). According to this 'selection perspective', parents neither divorce at random nor choose post-divorce family forms or residence models at random. Instead, the selection into divorce and separation is assumed to be the driver for adverse outcomes of parental separation. Evidence has been found for both perspectives (instability and selection), with the bulk of studies supporting the basic notion that divorce and separation negatively affect both children and adults (Amato 2010). Overall, scholarly research has become increasingly aware of the aspect of selection, even though it is virtually impossible to identify causal effects as such. A recent systematic review pointed to the need for a thorough empirical and theoretical differentiation between different events, like relationship formation and dissolution and fathers' and mothers' transitions; and argued in favour of recognising a wider range of outcomes and of contexts (Hadfield et al. 2018). 
The parents' socio-economic status and the resources they provide for their children are among the most intensively discussed issues related to divorce outcomes. The availability of resources can determine how well families deal with transitions. However, even children from families with adequate resources may experience substantial losses when their parents separate (Bernardi et al. 2019). The post-divorce losses of resources and their moderating roles are captured in the parental resource theory, which states that parents provide their children with two major resources: money, which meets the children's economic needs; and time, which allows parents to be involved in their children's lives, and to build strong parent-child relationships (Thomson et al. 1994). From this perspective, parental separation leads to a decline in both resources, as it reduces the involvement of the non-residential parent. When children lose access to the economic and social capital of one of their parents, their outcomes may be negatively affected. Thus, Sara McLanahan argued that family complexity may be seen from the perspective of 'diverging destinies' (McLanahan 2004; McLanahan and Jacobsen 2015). According to this perspective, children born to less educated mothers are especially likely to experience changes in family structure that are associated with a loss of resources, including early family formation, lower levels of paternal involvement, parental union dissolution, and weaker labour market attachment. The opposite pattern is observed for children born to highly educated mothers, who tend to benefit from their parents' later family formation, greater union stability, higher levels of paternal involvement, and stronger labour market attachment. As a consequence of these dynamics, parental divorce and separation affect the outcomes of children who are already socio-economically disadvantaged more than the outcomes of advantaged children, and lead to even greater disparities between these groups. In the long run, this accumulation of disadvantages produces further drawbacks over the life course and across generations among children with lower socio-economic status, while already privileged children continue to accumulate advantages.

\section{IMPACT OF DIVORCE AND SEPARATION ON CHILDREN, PARENTS, AND THEIR RELATIONS}

When parents divorce or separate, both the children and the parents need to adjust to the new situation. Numerous studies have linked parental divorce to children suffering from decreased emotional and psychological well-being, behavioural problems, lower educational achievement, impaired parental caregiving, and decreased economic resources and standards of living (Amato 2010; Bjarnason et al. 2012; Fomby and Cherlin 2007; Härkönen et al. 2017; Perkins 2019; Raley and Sweeney 2020). In the long run, (adult) children whose parents divorce have, on average, less frequent contact and a lower quality relationship with their non-resident parent (Amato and Cheadle 2005; Kalmijn 2015b). In addition, parental divorce leads to intergenerational transmission effects: i.e., children whose parents divorce are more likely to experience divorce in their own partnerships (Amato and Patterson 2017; Arocho 2019; Brown and Manning 2009; Wolfinger 2011). Moreover, rising rates of 'grey divorces' among older couples increasingly affect intergenerational solidarity between (adult) children and their divorced parents (Brown and Lin 2012).

Overall, there is 'a substantial degree of variability in children's outcomes following parental divorce, with some children declining, others improving, and most not changing at all' (Amato and Anthony 2014, p. 370). The average effects have been shown to be modest 
in magnitude and temporary, with most children and parents adjusting well over the medium term (Amato 2010; Raley and Sweeney 2020). However, the heterogeneity of such effects should be considered: i.e., the negative outcomes of parental separation tend to be concentrated among children from lower class families, while parents with more socio-economic resources seem to be better able to buffer their children from the detrimental effects of divorce (Amato and Anthony 2014; Grätz 2015).

Another essential question that arises in this context is whether increasing divorce and separation rates facilitate adaptation processes. The underlying assumption is that parental divorce and separation may be less stigmatised when it is more common. However, there is some evidence suggesting that the negative effects of a parental break-up on children can be even greater when divorce occurs in more families, as rising proportions of divorces are low-conflict break-ups. Children who are not exposed to parental conflict, tension, or hostility may find their parents' divorce especially hard to take, as it often comes as a surprise (Birnbaum and Saini 2012). While parental divorce can be beneficial in families with high levels of parental conflict (the so-called stress relief hypothesis), children from low-conflict families are more likely to be negatively affected by a parental break-up (Härkönen et al. 2017). Thus, when divorce becomes more common among low-conflict couples, more children will be negatively affected, and hence, the average effect of parental dissolution will become more negative (Kreidl et al. 2017).

\section{CHALLENGES FOR CHILDREN AND PARENTS IN POST-DIVORCE FAMILIES}

Dealing with a parental divorce or separation can put pressure on the parents, their children, and parent-child relations. The challenges these families face include having to cope with normative discrimination, preparations for (spatial) separation, the reorganisation of everyday family life, multiple transitions, and increased family complexity.

As divorce and separation rates have risen, family forms such as single-parent families and stepfamilies have become more common. It is often assumed that the social stigma attached to these family forms has decreased as their numbers have grown. However, several studies have found that the nuclear family ideology remains strong, and that attitudes towards parental separation, children of divorce, and non-nuclear family forms continue to be negative (Marschall 2016; Saint-Jacques et al. 2020; Zartler 2014). The powerful image of the nuclear family - two parents residing with their biological children - still affects people's ideas about how families should be composed, and how they ought to work. Normative understandings based on the nuclear family ideology disadvantage families who diverge from this iconic image, which is constructed in terms of deficits. Thus, non-nuclear families still have to deal with negative stereotypes.

In the preparation phase of a break-up, the parents are under pressure to find solutions for a broad range of issues, including questions regarding residence, custody, contact, and finances. From the perspective of the children, the demanding process of family reorganisation can feel less onerous if the children are given adequate, age-appropriate, and timely information about the divorce. Thus, receiving such information can ease the children's feelings of fear, anger, or guilt. Studies have shown that most children want to be better informed about the separation process and the consequences of their parents' separation for their own lives 
(Birnbaum and Saini 2012). Among the challenges divorcing parents face is finding the right words to inform their offspring of the break-up; to reassure them that the termination of the partner relationship will not change their love for their children; to explain in a child-friendly manner the reasons for the divorce; and to let the children know that their parents' decision to get divorced was not their fault.

Another major challenge parents and children are confronted with is the management of post-separation family lives. When the parents no longer reside permanently with their children, parenthood has to be practised (at least partly) at a distance. However, normative specifications and role models for such arrangements are rare. Qualitative and ethnographic studies have shown that multi-local parenting typically involves elaborated practices of presence and absence (Schier 2019). For children, shuttling between two family locations means that they are living 'double-looped' lives (Marschall 2017), and requires them to be attentive to each parent's distinct routines, expectations, demands, and parenting styles. Furthermore, practical issues - such as having all of the necessary clothing, equipment, school materials, etc. available in the right household at the right time - can make everyday life complicated for both the parents and children. Moreover, routines of coordination and communication between the households have to be established.

For children, a parental divorce can lead to many life changes, such as experiencing the departure of one parent from the household; having to move from their family home and relocate to a new neighbourhood and a new school; losing contact with their grandparents, friends, and classmates; suffering a decline in their standard of living; having to adapt to their parents' new partners or new family members, such as step or half-siblings; and having to cope with a series of subsequent parental break-ups. Accordingly, a multiple transition perspective treats divorce as one of a series of transitions that children may experience, with changes in the parents' partnership status representing and inducing the most influential alterations. The nature, the number, and the timing of such transitions are crucial factors in whether children are able to adapt successfully to their post-divorce living situations; especially given that each transition demands further adaptation and the renegotiation of roles and routines. According to stress theory, when children and their parents experience a large number of changes within a short time - as is often the case when the parents divorce - their stress is likely to be cumulative, which could have negative effects on their health and well-being over the longer term (Amato 2010; Amato and Sobolewski 2001; Osborne and McLanahan 2007; Raley and Sweeney 2020; Shafer et al. 2017). However, qualitative studies have shown that children and parents employ diverse strategies in an attempt to reduce the negative impact of transitions (Hadfield and Nixon 2018; Zartler 2014). Recent research has also found evidence of gender-differentiated effects: i.e., that the well-being of adolescents with divorced parents is negatively affected when their mother's post-divorce relationship history is unstable, but also when their father's post-divorce relationship history is stable (Bastaits et al. 2018). This finding may be attributed to the dynamics that are set in motion by the introduction of a stepparent to the paternal household (e.g., the addition of stepsiblings, potential geographical moves or changes in custody arrangements, or the redistribution of the father's time and economic resources).

Furthermore, family complexity is associated with major challenges. Gaining a stepparent after a parental separation is a common experience for many children. In most European countries, around 30 to 40 per cent of children with divorced parents were living in a stepfamily within six years of the parental break-up, and more than one-third of children who were born to 
a lone mother acquired a stepfather before their sixth birthday (Andersson et al. 2017). There is also evidence that the intensity of contact between non-resident parents (mostly fathers) and their children tends to decrease when either the mother or the father re-partners, and that children in stepfamilies tend to have lower well-being than those living with both biological parents (Härkönen et al. 2017). A potential explanation for these findings is that the presence of a stepparent and/or step or half-siblings makes family relationships more complex, as relationships between (new) family members and kin have to be renegotiated, a range of contact and custody agreements have to be synchronised and reorganised, family boundaries become volatile, and feelings of family belonging are challenged (Ganong and Coleman 2017). Thus, increased family complexity may exacerbate feelings of stress and concerns about family boundaries (Brown and Manning 2009; Fomby and Cherlin 2007; Shafer et al. 2017; Stewart 2005). Having a new partnership can also impose time constraints and additional responsibilities on a parent that may interfere with the family's established routines and contact agreements. Moreover, family complexity can lead to the uneven distribution of resources. For example, (step)parents are likely to put more resources into their biological children than their stepchildren, and into the children with whom they share a household than the children with whom they are no longer living (Köppen et al. 2018; Tach et al. 2014). Furthermore, a disproportionate number of stepfamilies are formed by nonmarital couples, whose unions are more likely to be unstable; and, even if such couples get married, these new unions tend to be less stable than first marriages. Thus, children living in stepfamilies face a high risk of experiencing a further separation (Cherlin 2017).

\section{CUSTODY AND CONTACT AFTER PARENTAL DIVORCE}

One of the most crucial and controversial issues in post-divorce families is the organisation of parental responsibilities. In most cases, a parental divorce reduces the frequency of a child's contact with the non-resident parent (usually the father). However, in recent decades, the legal construction of parental roles has changed enormously, with fathers' rights being extended, while the practice of routinely granting sole custody to the mother (and contact rights to the father) has receded. The most notable legal development in this context has been the introduction of joint legal custody in many European countries; i.e., the equal distribution of legal rights to both parents, regardless of whether they are living with the child and the legal status of their former partnership. In a joint legal custody arrangement, the parents have to cooperate when making important decisions concerning their child's everyday life; while in a joint physical custody arrangement, the child spends equal amounts of time in each parent's household. Simultaneously, in many countries, protecting the child's best interests has been elevated to the leading juridical principle in all issues regarding custody and contact rights, with the goal being to ensure that the child maintains a close relationship with both parents, even in cases in which the parental relationship is marked by conflict (Cancian et al. 2014; Zartler and Hierzer 2015).

Despite these legal changes, a majority of children whose parents divorce still spend more time in the maternal than the paternal home, and often spend shorter periods outside of the weekday routine with their father (Bjarnason and Arnarsson 2011). Overall, it is difficult to quantify the exact durations of time that children spend with each parent. While the extent of non-resident fathers' contact with their children has been intensively researched for the United 
States, the United Kingdom, and Canada, there is much less evidence on this question for continental Europe (for an overview, see Kalmijn 2015a; Köppen et al. 2018). Moreover, levels of father-child contact vary greatly: while some fathers maintain frequent contact, others lose contact completely. In his study of 14-year-old children living in four European countries (England, Germany, the Netherlands, Sweden), Kalmijn (2015a) showed that the majority of children had good or very good ties to their father, while one in six children did not see their father at all. Furthermore, contact frequency tends to decrease with increasing duration since the separation. In seeking to explain this heterogeneity, the existing research has, for example, observed that fathers who have co-resided with the mother of their children prior to the separation, who have been married, who are highly educated and socio-economically advantaged, and who have joint legal custody are more likely than fathers who lack these characteristics to remain involved in their children's lives after separation (Kalmijn 2015a; Köppen et al. 2018; Tach et al. 2014).

Emotionally satisfying parent-child relationships are beneficial for parents and children. Although regular contact appears to be helpful in maintaining father-child bonds and developing an orderly routine, pre-divorce parental involvement, rather than post-divorce contact frequency, appears to be the main factor in the quality of such relationships. Thus, a child's well-being depends heavily on the level of paternal involvement in childrearing before the parental break-up, and a child is likely to benefit from regular contact with his/her father only if the father's level of pre-divorce involvement was medium or high. Thus, 'it is not so much the frequency of contact per se that matters for child well-being but, rather, the extent to which post-divorce residence arrangements reflect predivorce parenting arrangements' (Poortman 2018, p. 671). Apart from the sheer quantity of contact, qualitative aspects of the contact are also important, such as the quality of the father-child relationship, and how the father and child spend their time together (Palkovitz 2019). In addition to examining what makes parentchild relationships satisfying, research has identified the co-parental relationship as a key factor in children's well-being and adjustment levels after divorce (Amato 2000; Becher et al. 2019). Cooperative co-parenting that facilitates both parents' positive involvement in their child's life seems to be more suitable than parallel parenting, which is characterised by low communication and high conflict levels. However, the notion that a cooperative co-parental relationship represents a 'good divorce', and can protect children comprehensively from negative outcomes, has been challenged (Amato et al. 2011). Thus, it is clear that for most children, divorce is an unwanted and often painful experience.

A crucial component of post-divorce family reorganisation is the division of the time the child spends with each parent. There are different legal models of physical custody that have been designed with the child's best interests in mind. However, opinions about which of these custody models are best suited to meeting this goal have changed substantially in recent years. As the legal understanding of the child's position and of parent-child relations has evolved, custodial arrangements after a divorce no longer automatically follow the standard model of sole custody (mainly by mothers), and are increasingly likely to follow the joint physical custody or shared residence model, in which the child spends (approximately) equal amounts of time with both parents, usually defined as a ratio of 50:50 up to a ratio of 70:30. In some countries that have a longer history of shared residence and established joint physical custody as the primary legal custodial arrangement, such as Belgium or Sweden, the share of child custody cases with joint physical custody arrangements is 30 per cent or higher; while in other countries, this share is much lower, at 10 to 15 per cent (Steinbach 2019). In a study 
based on the child's perspective, Bjarnason and Arnarsson (2011) showed that in 29 out of 36 Western countries, 1 per cent or less of all children aged 11, 13, and 15 years were spending equal amounts of time with their mother and father in two separate households. This share was about 2 per cent in Norway, the United Kingdom, Canada, and the United States; 3 per cent in Belgium, Denmark, and Iceland; and 4 per cent in Sweden. The study also found that shared residence was mainly practised when the child was attending primary school or in early adolescence. Overall, it appears that this model is used by a highly selective group of parents characterised by low levels of conflict, high levels of parental involvement, high educational attainment and socio-economic status, and comprehensive economic resources (Poortman and van Gaalen 2017; Steinbach 2019).

In terms of consequences, several meta-analyses have shown that shared residence can have positive effects on the well-being of children and their parents (Baude et al. 2016; Bauserman 2012; Nielsen 2014; Smyth 2017; Steinbach 2019), and can be beneficial for post-divorce parent-child relationships in terms of communication and support (Bastaits and Pasteels 2019). While this is generally the case if parents cooperate and have low levels of conflict, there is scholarly disagreement about the impact of joint physical custody on children if the parents do not cooperate or have ongoing conflicts. Most studies that have examined this question have found that parents, and fathers in particular, are more satisfied with shared residence than children; and that children in joint physical custody arrangements seem to fare as well or slightly better than children in sole physical custody arrangements (Steinbach 2019). Overall, the differences in the effects of the different residence models tend to be modest. Studies that have captured children's perspectives have observed that while such arrangements make it easier for children to maintain satisfying relationships with both parents, they are also associated with high logistical demands and high levels of stress due to ongoing adaptation processes and limited social interconnections between the two households, and that children would like to have more flexibility and participation regarding custody schedules and arrangements than their parents realise (Marschall 2017; Merla 2018; Zartler and Grillenberger 2017; Kitterød and Lidén 2020).

In sum, a wide range of factors should be considered when assessing the merits of physical custody arrangements, and individual solutions should be adapted to each family's specific situation. Moreover, agreements must be adapted over time as children grow older, and their needs and daily routines change. It is difficult to generalise the results of the existing studies on this topic, as they vary greatly in terms of the definitions used, the legal contexts, the sample sizes and data quality, the ages and the numbers of the children studied, and the duration of shared residence covered. Furthermore, knowledge about alternative models, such as 'bird's nest' custody (in which the parents move between households, and the children remain in their stable family household), is scarce to non-existent due to the low prevalence of such arrangements. Overall, the findings regarding the risks and benefits of joint physical custody are mixed or even contradictory, and thus remain unclear. In light of these results and taking into account the socio-economic selectivity associated with this custody model, policy changes that would make joint physical custody the default solution in child custody cases should be scrutinised carefully. 


\section{CONCLUSION}

Parental divorce is always connected with major changes and transitions for both children and their parents. A plethora of studies have examined children's well-being after a parental union break-up, and concluded that a number of moderators and stressors contribute to children's healthy adaptation to these changes. While these results are not entirely coherent, they generally suggest that parental resources have a protective effect. These resources include not only the parents' socio-economic status, but their ability and willingness to communicate and co-parent effectively. Even though a parental break-up has some long-term consequences for families, most children and parents who experience such disruptions adapt to their new situations in the medium run. However, additional transitions that lead to more family complexity can be difficult for family members, leading to increasing stress, family boundary ambiguity, and reduced well-being. Post-divorce families face numerous challenges, such as dealing with normative disadvantages, parent-child communication prior to the divorce, and management of post-separation family arrangements. Establishing contact and custody arrangements is among the primary issues parents have to negotiate in order to maintain emotionally satisfying bonds with their children, and to support their well-being. Overall, there is no 'one size fits all' solution for all post-separation families, and physical custody arrangements have to be adapted to each family's particular needs As these arrangements also need to be modified over time, a continuous process of negotiation between the separated parents is indispensable, which places additional pressure on post-divorce families. Research has shown that the lives of children and parents are interwoven even when they are no longer part of the same household, and that interconnections of their 'linked lives' persist across the life course well into adulthood.

It is essential to recognise that the divorce does not exist, just as there is no such thing as the post-divorce family or the parent-child relationship after parental break-up. As the processes that lead up to divorce and that accompany its aftermath vary considerably, post-divorce families are also very different. Like all other families, these families are the meeting ground of 'multiple realities' (Larson and Richards 1995, p. 189), especially in cases of conflict. This is an important point, as focusing on an imagined 'average' of transitions, causes, or effects hides the differences that exist between and within post-divorce families. Therefore, future research is needed to capture, reconstruct, and interpret the different experiences and standpoints of individual family members, as well as the heterogeneity within and between families. The differences in how well children and their parents adjust following a parental divorce also require further explanation. In addition, more research is needed on the similarities or disparities between different types of separation (e.g., low- or high-conflict break-ups; unexpected divorces versus those that were long anticipated) and their implications over the life course. At the same time, the enormous heterogeneity of custody and contact arrangements, and how they affect the everyday lives of families, are issues that demand scholarly attention. Furthermore, how separations affect families in different social, legal, and normative contexts and in different geographical regions should be examined. Moreover, geographical distances between parental households need to be considered, as a child's divorced parents can live as close as on the same street, or as far away as in different countries, requiring hours-long trips by train, car, or airplane.

Solving the heterogeneity puzzle raises a number of questions, including the following: How do the consequences of a parental break-up for children differ depending on whether it is a formal divorce or the separation of an informal cohabiting union? How do the consequences 
of a parental break-up for children differ depending on whether the break-up is of a stepfamily or of their biological parents? In precisely what ways do multiple transitions impose strains on children and parents; and, conversely, how, why, and under what circumstances is stability beneficial? How are resources such as money and time distributed between different sets of children in complex post-divorce families, and what criteria are used to do so? How are legal arrangements negotiated with different family members, and how and to what extent do children participate in parental decisions about custody, care, and contact? How do children and parents manage great geographical distances, or even the desire to relocate a child from one country to another?

Examining complex families and blurred family boundaries is methodologically challenging. As scholars are increasingly recognising that children are active and competent actors in their own right, it is becoming more common to include children's perspectives in research. However, as divorce is a sensitive issue, scholars who wish to study it need the right methodological tools and competence, and adequate resources. Future research on divorce should try to capture the perspectives and experiences not only of the divorcing partners and their children, but of other family members. Moreover, while it is generally acknowledged that divorce is a process, empirical research on divorce often focuses on the event, and is usually based on cross-sectional data. In order to better capture the dynamics of divorce and to analyse the evolution of post-divorce family relationships over time, future research should adopt a longitudinal approach.

\section{NOTE}

1. In this chapter, the terms (parental) divorce and separation - i.e., dissolution of marital and non-marital unions - are used interchangeably. While there are fundamental legal differences between divorce and separation, many of their consequences for parent-child relations are similar.

\section{REFERENCES}

Amato, P.R. (2000), 'The consequences of divorce for adults and children', Journal of Marriage and Family, 62 (4), 1269-87. doi:10.1111/j.1741-3737.2000.01269.x.

Amato, P.R. (2010), 'Research on divorce: Continuing trends and new developments', Journal of Marriage and Family, 72 (3), 650-66. doi:10.1111/j.1741-3737.2010.00723.x.

Amato, P.R. and C.J. Anthony (2014), 'Estimating the effects of parental divorce and death with fixed effects models', Journal of Marriage and Family, 76 (2), 370-86. doi:10.1111/jomf.12100.

Amato, P.R. and J. Cheadle (2005), 'The long reach of divorce: Divorce and child well-being across three generations', Journal of Marriage and Family, 67 (1) 191-206. doi:10.1111/j.0022-2445.2005 .00014.x.

Amato, P.R. and S.E. Patterson (2017), 'The intergenerational transmission of union instability in early adulthood', Journal of Marriage and Family, 79 (3), 723-38. doi:10.1111/jomf.12384.

Amato, P.R. and J.M. Sobolewski (2001), 'The effects of divorce and marital discord on adult children's psychological well-being', American Sociological Review, 66 (6), 900-21. doi:10.2307/3088878.

Amato, P.R., J.B. Kane, and S. James (2011), 'Reconsidering the "good divorce"', Family Relations, 60 (5), 511-24. doi:10.1111/j.1741-3729.2011.00666.x.

Andersson, G., E. Thomson, and A. Duntava (2017), 'Life-table representations of family dynamics in the 21st century', Demographic Research, 37 (35), 1081-230. doi:10.4054/DemRes.2017.37.35.

Arocho, R. (2019), 'Do expectations of divorce predict union formation in the transition to adulthood?', Journal of Marriage and Family, 81 (4), 979-90. doi:10.1111/jomf.12571. 
Bastaits, K. and I. Pasteels (2019), 'Is joint physical custody in the best interests of the child? Parentchild relationships and custodial arrangements', Journal of Social and Personal Relationships, 36 (11-12), 3752-72. doi:10.1177/0265407519838071.

Bastaits, K., I. Pasteels, and D. Mortelmans (2018), 'How do post-divorce paternal and maternal family trajectories relate to adolescents' subjective well-being?', Journal of Adolescence, 64, 98-108. doi:10 .1016/j.adolescence.2018.02.005.

Baude, A., J. Pearson, and S. Drapeau (2016), 'Child adjustment in joint physical custody versus sole custody: A meta-analytic review', Journal of Divorce and Remarriage, 57 (5), 338-60. doi:10.1080/ 10502556.2016.1185203.

Bauserman, R. (2012), 'A meta-analysis of parental satisfaction, adjustment, and conflict in joint custody and sole custody following divorce', Journal of Divorce and Remarriage, 53 (6), 464-88. doi:10 $.1080 / 10502556.2012 .682901$.

Becher, E.H., H. Kim, S.E. Cronin, V. Deenanath, J.K. McGuire, E.M. McCann, and S. Powell (2019), 'Positive parenting and parental conflict: Contributions to resilient co-parenting during divorce', Family Relations, 68 (1), 150-64. doi:10.1111/fare.12349.

Bernardi, F., D. Boertien, and K. Geven (2019), 'Childhood family structure and the accumulation of wealth across the life course', Journal of Marriage and Family, 81 (1), 230-47. doi:10.1111/jomf .12523 .

Birnbaum, R. and M. Saini (2012), 'A scoping review of qualitative studies about children experiencing parental separation', Childhood 20 (2), 260-82. doi:10.1177/0907568212454148.

Bjarnason, T. and A.M. Arnarsson (2011), 'Joint physical custody and communication with parents: A cross-national study of children in 36 western countries', Journal of Comparative Family Studies, 42 (6), 871-90. doi:10.2307/41604494.

Bjarnason, T., P. Bendtsen, A.M. Arnarsson, I. Borup, R.J. Iannotti, P. Löfstedt, I. Haapasalo, and B. Niclasen (2012), 'Life satisfaction among children in different family structures: A comparative study of 36 western societies', Children and Society, 26 (1), 51-62. doi:10.1111/j.1099-0860.2010.00324.x.

Boss, P.G. and J. Greenberg (1984), 'Family boundary ambiguity: A new variable in family stress theory', Family Process, 23, 535-46. doi:org/10.1111/j.1545-5300.1984.00535.x.

Brown, S.L. and I.-F. Lin (2012), 'The gray divorce revolution: Rising divorce among middle-aged and older adults 1990-2010', Journals of Gerontology Series B: Psychological Sciences and Social Sciences, 67 (6), 731-41. doi:10.1093/geronb/gbs089.

Brown, S.L. and W.D. Manning (2009), 'Family boundary ambiguity and the measurement of family structure: The significance of cohabitation', Demography, $\mathbf{4 6}$ (1), 85-101. doi:10.1353/dem.0.0043.

Cancian, M., D.R. Meyer, P.R. Brown, and S.T. Cook (2014), 'Who gets custody now? Dramatic changes in children's living arrangements after divorce', Demography, 51 (4), 1381-96. doi:10.1007/ s13524-014-0307-8.

Castrén, A.-M. and E.D. Widmer (2015), 'Insiders and outsiders in stepfamilies: Adults' and children's views on family boundaries', Current Sociology, 63 (1), 35-56. doi:10.1177/0011392114551650.

Cherlin, A. (1999), 'Going to extremes: Family structure, children's well-being, and social science', Demography, 36 (4), 421-8. 10.2307/2648081.

Cherlin, A. (2017), 'Introduction to the special collection on separation, divorce, repartnering, and remarriage around the world', Demographic Research, 37 (38), 1275-96. doi:10.4054/DemRes.2017 .37 .38 .

Fomby, P. and A.J. Cherlin (2007), 'Family instability and child well-being', American Sociological Review, 72, 181-204. doi:10.1177/000312240707200203.

Ganong, L. and M. Coleman (2017), 'Studying stepfamilies: Four eras of family scholarship', Family Process, 57 (1), 7-24. doi:10.1111/famp.12307.

Grätz, M. (2015), 'When growing up without a parent does not hurt: Parental separation and the compensatory effect of social origin', European Sociological Review, 31 (5), 546-57. doi:10.1093/esr/jcv057.

Hadfield, K. and E. Nixon (2018), “'He's had enough fathers”: Mothers' and children's approaches to mothers' romantic relationships following the dissolution of previous partnerships', Journal of Family Issues, 39 (1), 271-95. doi:10.1177/0192513×16638385.

Hadfield, K., M. Amos, M. Ungar, J. Gosselin, and L. Ganong (2018), 'Do changes to family structure affect child and family outcomes? A systematic review of the instability hypothesis', Journal of Family Theory and Review, 10 (1), 87-110. doi:10.1111/jftr.12243. 


\section{Research handbook on the sociology of the family}

Härkönen, J., F. Bernardi, and D. Boertien (2017), 'Family dynamics and child outcomes: An overview of research and open questions', European Journal of Population, 33 (2), 163-84. doi:10.1007/ s10680-017-9424-6.

Kalmijn, M. (2015a), 'Father-child relations after divorce in four European countries: Patterns and determinants', Comparative Population Studies, 40 (3), 251-76. doi:10.12765/CPoS-2015-10en.

Kalmijn, M. (2015b), 'How childhood circumstances moderate the long-term impact of divorce on father-child relationships', Journal of Marriage and Family, 77 (4), 921-38. doi:10.1111/jomf.12202.

Kitterød, R. H., and H. Lidén (2020), 'Children in dual-residence arrangements: Exploring discourses of fairness and children's best interest in Norway', Children \& Society, 1-14. doi: 10.1111/chso.12424

Köppen, K., M. Kreyenfeld, and H. Trappe (2018), 'Loose ties? Determinants of father-child contact after separation in Germany', Journal of Marriage and Family, 80 (5), 1163-75. doi:10.1111/jomf .12504 .

Kreidl, M., M. Štípková, and B. Hubatková (2017), 'Parental separation and children's education in a comparative perspective: Does the burden disappear when separation is more common?', Demographic Research, 36 (3), 73-110. www.jstor.org/stable/26332126.

Larson, R. and M.H. Richards (1995), Divergent Realities: The Emotional Lives of Mothers, Fathers and Adolescents, New York: Basic Books.

Marschall, A. (2016), 'Children's perspectives on post-divorce family life: Continuity and change', in S. Grant (ed.), Divorce: Risk Factors, Patterns and Impact on Children's Wellbeing, New York: Nova Science Publishers, pp. 117-30.

Marschall, A. (2017), 'When everyday life is double looped: Exploring children's (and parents') perspectives on post-divorce family life with two households', Children and Society, 31 (5), 342-52. doi:10 $.1111 /$ chso.12202.

McLanahan, S. (2004), 'Diverging destinies: How children are faring under the second demographic transition', Demography, 41 (4), 607-27. doi:10.1353/dem.2004.0033.

McLanahan, S. and W. Jacobsen (2015), 'Diverging destinies revisited', in P.R. Amato et al. (eds), Families in an Era of Increasing Inequality: Diverging Destinies, Geneva: Springer, pp. 3-23.

Merla, L. (2018), 'Rethinking the interconnections between family socialization and gender through the lens of multi-local, post-separation families', Sociologica, 12 (3), 47-57. doi:10.6092/issn .1971-8853/9085.

Nielsen, L. (2014), 'Shared physical custody: Summary of 40 studies on outcomes for children', Journal of Divorce and Remarriage, 55 (8), 613-35. doi:10.1080/10502556.2014.965578.

Osborne, C. and S. McLanahan (2007), 'Partnership instability and child well-being', Journal of Marriage and Family, 69 (4), 1065-83. doi:10.1111/j.1741-3737.2007.00431.x.

Palkovitz, R. (2019), 'Expanding our focus from father involvement to father-child relationship quality', Journal of Family Theory and Review, 11 (4), 576-91. doi:10.1111/jftr.12352.

Perkins, K.L. (2019), 'Changes in household composition and children's educational attainment', Demography, 56 (2), 525-48. doi:10.1007/s13524-018-0757-5.

Poortman, A.-R. (2018), 'Postdivorce parent-child contact and child well-being: The importance of predivorce parental involvement', Journal of Marriage and Family, 80 (3), 671-83. doi:10.1111/jomf .12474 .

Poortman, A.-R. and R. van Gaalen (2017), 'Shared residence after separation: A review and new findings from the Netherlands', Family Court Review, 55 (4), 531-44. doi:10.1111/fcre.12302.

Raley, R.K. and M. Sweeney (2020), 'Divorce, repartnering, and stepfamilies: A decade in review', Journal of Marriage and Family, 82 (1), 81-99. doi:10.1111/jomf.12651.

Saint-Jacques, M.-C., E. Godbout, and H. Ivers (2020), 'People's opinions and stereotypes about stepfamilies', Journal of Family Issues, 41 (11), 2136-59. doi:10.1177/0192513X19896060.

Schier, M. (2019), 'Fatherhood post-separation: Practicing fathering from a distance and in brief co-present phases', in M. Halatcheva-Trapp et al. (eds), Family and Space: Rethinking Family Theory and Empirical Approaches, London: Routledge, pp. 170-80.

Shafer, K., T.M. Jensen, and E.K. Holmes (2017), 'Divorce stress, stepfamily stress, and depression among emerging adult stepchildren', Journal of Child and Family Studies, 26 (3), 851-62. doi:10 $.1007 / \mathrm{s} 10826-016-0617-0$.

Smyth, B.M. (2017), 'Special issue on shared-time parenting after separation', Family Court Review, 55 (4), 494-9. doi:10.1111/fcre.12299. 
Steinbach, A. (2019), 'Children's and parents' well-being in joint physical custody: A literature review', Family Process, 58 (2), 353-69. doi:10.1111/famp.12372.

Stewart, S.D. (2005), 'Boundary ambiguity in stepfamilies', Journal of Family Issues, 26 (7), 1002-29. doi: $10.1177 / 0192513 \times 04273591$.

Tach, L., K. Edin, H. Harvey, and B. Bryan (2014), 'The family-go-round: Family complexity and father involvement from a father's perspective', Annals of the American Academy of Political and Social Science, 654 (1), 169-84. doi:10.1177/0002716214528655.

Thomson, E., T.L. Hanson, and S.S. McLanahan (1994), 'Family structure and child well-being: Economic resources vs. parental behaviors', Social Forces, 73 (1), 221-42. doi:10.2307/2579924.

Wolfinger, N.H. (2011), 'More evidence for trends in the intergenerational transmission of divorce: A completed cohort approach using data from the general social survey', Demography, 48 (2), 581-92. doi:10.1007/s13524-011-0025-4.

Zartler, U. (2011), 'Reassembling families after divorce', in R. Jallinoja and E. Widmer (eds), Families and Kinship in Contemporary Europe: Rules and Practices of Relatedness, Basingstoke: Palgrave Macmillan, pp. 178-91.

Zartler, U. (2014), 'How to deal with moral tales: Constructions and strategies of single-parent families', Journal of Marriage and Family, 76 (3), 604-19. doi:10.1111/jomf.12116.

Zartler, U. and K. Grillenberger (2017), 'Doubled homes, doubled social ties? Children's relationships in post-divorce shared residence arrangements', Children and Society, 31 (2), 144-56. doi:10.1111/ chso.12194.

Zartler, U. and J. Hierzer (2015), 'Efforts to cut the Gordian knot: A sociological analysis regarding legal aspects of post-divorce parental responsibility', in U. Zartler, V. Heintz-Martin, and O. Arránz Becker (eds), 'Family Dynamics after Separation', special issue of Journal of Family Research, Leverkusen: Barbara Budrich, 219-37. 